\title{
THERMAL AND GEOCHEMICAL SIGNATURE OF POÁS VOLCANO, COSTA RICA (MARCH 2009)
}

\author{
FIRMA TÉRMICA Y GEOQUÍMICA DEL VOLCÁN POÁS, \\ COSTA RICA (MARZO 2009)
}

Letizia Spampinato $^{1,2 *}$, Giuseppe G. Salerno ${ }^{1,2}$, Robert S. Martin ${ }^{3}$, Georgina M. Sawyer ${ }^{2}$, Clive Oppenheimer $^{2}$, Evgenia Ilyinskaya ${ }^{2} \&$ Carlos Ramírez ${ }^{4}$

${ }^{1}$ Istituto Nazionale di Geofisica e Vulcanologia, sezione di Catania, Piazza Roma, 2, 95123, Catania, Italy

${ }^{2}$ Department of Geography, University of Cambridge, Downing Place, Cambridge, CB2 3EN, United Kingdom

${ }^{3}$ School of Biological and Chemical Sciences, Queen Mary, University of London, Mile End Road, London, E1 4NS, United Kingdom

${ }^{4}$ Centro de Investigaciones en Ciencias Geológicas (CICG), University of Costa Rica, Costa Rica *Autora para contacto: letizia.spampinato@ct.ingv.it

(Recibido: 19/07/2009; aceptado: 08/11/2010)

\begin{abstract}
We report results from a multidisciplinary campaign conducted at Poás volcano (Costa Rica) in March 2009. Thermal imagery of the fumaroles sited on the north side of the pyroclastic cone revealed mean apparent temperatures ranging between 25 and $40^{\circ} \mathrm{C}$ with a maximum apparent temperature of $80^{\circ} \mathrm{C}$. The crater lake surface was characterised by mean apparent temperatures varying between 30 and $35^{\circ} \mathrm{C}$ and a maximum recorded value of $48^{\circ} \mathrm{C}$. Thermal profiles across the lake surface revealed steady temperatures and thus thorough convective mixing. The overall mean $\mathrm{SO}_{2}$ flux emitted from the crater was $76 \mathrm{Mg} \mathrm{d}^{-1}$, with approximately equal contributions from both the pyroclastic cone and the lake. Analysis of gas composition using active, open-path FTIR spectroscopy indicated molar ratios of $\mathrm{H}_{2} \mathrm{O} / \mathrm{SO}_{2}=151, \mathrm{CO}_{2} / \mathrm{SO}_{2}=1.56, \mathrm{SO}_{2} / \mathrm{HCl}>40$, and $\mathrm{SO}_{2} / \mathrm{HF}>200$ for the lake emission. The plume was also sampled using filter packs. Ion chromatographic analysis revealed the presence of abundant $\mathrm{K}^{+}$and $\mathrm{SO}_{4}{ }^{2-}$, with small amounts of $\mathrm{Ca}^{2+}, \mathrm{Cl}^{-}$, and $\mathrm{Mg}^{2+}$. This provides a detailed picture of lake surface temperature characteristics and of gas flux and composition of the plume emitted from Poás. The results are consistent with the typical non-eruptive state of this volcano. Keywords: Thermal imagery, $\mathrm{SO}_{2}$ flux, FTIR, Poás.
\end{abstract}


RESUMEN: Nosotros reportamos resultados de una campaña multidisciplinaria conducida en el volcán Poás (Costa Rica) en Marzo del 2009. Imágenes térmicas de las fumarolas situadas en el lado norte del domo revelan una temperatura significativa aparente que oscila entre 25 y $40^{\circ} \mathrm{C}$ con una temperatura máxima aparente de $80^{\circ} \mathrm{C}$. La superficie del lago cratérico fue caracterizada por temperaturas significativas aparentes variantes entre 30 a $35^{\circ} \mathrm{C}$ y un valor máximo registrado de $48^{\circ} \mathrm{C}$. Perfiles térmicos a través de la superficie del lago revelan temperaturas firmes y además una minuciosa mezcla convectiva. El flujo total $\mathrm{SO}_{2}$ significativo emitido desde el cráter fue $76 \mathrm{Mg} \mathrm{d}^{-1}$, con aproximadamente contribuciones equitativas de ambos el domo y el lago. Análisis de la composición del gas usando espectroscopia activa FTIR con ruta abierta, indico proporciones molares de $\mathrm{H}_{2} \mathrm{O} / \mathrm{SO}_{2}=151, \mathrm{CO}_{2} / \mathrm{SO}_{2}=1.56, \mathrm{SO}_{2} / \mathrm{HCL}>40, \mathrm{Y} \mathrm{SO} / \mathrm{HF}>$ 200 para la emisión del lago. La pluma fue también muestreada usando paquetes de filtros. Análisis del cromatógrafo iónico revelan la abundante presencia de $\mathrm{K}^{+}$y $\mathrm{SO}_{4}^{-2}$, con pequeñas cantidades de $\mathrm{Ca}^{2+}, \mathrm{Cl}^{-}$, y $\mathrm{Mg}^{2+}$. Esto provee una imagen detallada de las características de la temperatura de la superficie del lago y del flujo de gas y composición de la pluma emitida por Poás. Los resultados son consistentes con el típico estado no-eruptivo de este volcán.

Palabras clave: Imagen térmica, flujo $\mathrm{SO}_{2}$, FTIR, Poás.

\section{INTRODUCTION}

Poás is a basaltic-andesite composite volcano located within the Cordillera Central in Costa Rica. The volcano summit rises $\sim 2700 \mathrm{~m}$ a.s.1. and consists of three distinct eruptive centres roughly aligned NW-SE, of which the presently active (Laguna Caliente) lies between the two older centres (e.g., Melián et al., 2007; Fig. 1). The activity of Laguna Caliente is characterised by a long history of sporadic phreatic eruptions and persistent fumarolic emissions (Lopes, 2005). The crater $(1.3 \mathrm{~km}$ in diameter, Casertano et al., 1987) includes a 300 m-diameter pit hosting a 30$60^{\circ} \mathrm{C}$, acidic ( $\mathrm{pH} \sim 0$ ) lake, and a $\sim 30 \mathrm{~m}$ high pyroclastic cone, referred to as the "dome" (Rymer et al., 2000). The dome was constructed from tephra during the 1953-55 phreatomagmatic eruption and is not a lava dome in the conventional sense (e.g., Casertano et al., 1985; Rowe et al., 1992a).

In 1981, preceded by a regional earthquake (Rymer et al., 2000), a shallow magma intrusion beneath the dome triggered an increase in fumarole temperatures from 92 to $\sim 1000^{\circ} \mathrm{C}$ (Casertano et al., 1987) and $\mathrm{SO}^{2}$ fluxes up to $\sim 700 \mathrm{Mg} \mathrm{d}-1$ (Casadevall et al., 1984; Andres et al., 1992). In June 1987, an intense period of phreatic eruptions began (SMITHSONIAN, 1987). From 1987-89, the lake level fell gradually, eventually revealing a muddy floor, where a number of boiling mud pools, and $\sim 1-3$ m-high yellow ephemeral cones formed (Oppenheimer \& Stevenson, 1989). The cones were composed of sulphur pyroclastics (largely accretionary lapilli) and were sites of vigorous gas emission (Oppenheimer, 1992). Following the draining of the lake, there were a number of phreatic eruptions during 1989-90 (e.g., Sanford et al., 1995). Then in 1995-97, the lake re-established, with a water level higher than before the crisis (Ramírez et al., 2010) and fumarolic activity on the dome increased in 1997-98 as the lake level rose (Mora et al., 2004). Since 1997, the activity at Poás has consisted of variable seismic and fumarolic activity, a fluctuating lake water level, and small phreatic eruptions i.e. on 24 March 2006, 25 September 2006, December 2006, and 13 January 2008 (Mora et al., 2004; Ramírez et al., 2007). The most recent seismic event and phreatic explosion occurred on 8 and 12 January 2009, respectively (RSN, 2009). The local earthquake promoted the opening of new fractures around the crater rim and rock slides whose debris accumulated on the crater floor. Degassing from the crater increased in intensity and the colour of the lake water changed with the appearance of yellow sulphur bands (RSN, 2009). Three minor phreatic eruptions ejected sediments and water to a height of $\sim 25 \mathrm{~m}$ within the crater, affecting an area of $\sim 100 \mathrm{~m}$ in diameter (Ramírez et al., 2010). 
The lake plays an important role in the magmatic-hydrothermal system of the volcano (Brown et al., 1989; Oppenheimer \& Stevenson, 1989; Rymer et al., 2000), and variations in its mass, energy and chemical balances can develop feedbacks involving the shallow magmatic system. The lake size, level, temperature and composition are not only controlled by seasonal effects and hydrological features, but also by volcanic activity (Brown et al., 1989; Martínez et al., 2000; Ramírez et al., 2010). The tracking of parameters such as temperature (Oppenheimer, 1993; Vaselli et al., 2003; Mora et al., 2004; Trunk \& Bernard, 2008), water composition (Rowe et al., 1992b; Zimmer et al., 2004), plume chemistry (Pfeffer et al., 2006), seismicity (Casertano et al., 1987), ground deformation (Rymer et al., 2000), and gravimetry (e.g., Rymer \& Brown, 1989) have been critical for the assessment of magma intrusion, and thus for civil protection purposes, especially after the 1953-55 and the 1980s eruptive episodes, which caused severe damage to the local environment and agriculture (Rymer et al., 2005). Additionally, gases emitted by the volcano may result in significant impacts on human health (e.g., Oppenheimer, 1992; Hansell \& Oppenheimer, 2004).
Here we report the results of a field campaign carried out at Poás volcano during 17-18 March 2009 using a range of remote sensing and direct sampling techniques. These include thermal imaging, ultraviolet Differential Optical Absorption Spectroscopy (DOAS), Fourier Transform InfraRed (FTIR) spectroscopy, and filter pack sampling. The integration of the different retrieved parameters yields a detailed characterisation of the crater lake's activity. The relative ease of access to Poás has enabled intense geophysical research and monitoring campaigns to be undertaken (e.g., Rymer et al., 2000). These have provided new insights into the volcano's subsurface architecture leading to modelling of the magmatic and hydrothermal system dynamics. Our geochemical and thermal inventory offers a new multidisciplinary contribution to the knowledge and study of the volcano.

\section{METHODS}

\section{Thermal Imagery}

During the two-day survey, a total of 3100 radiometric images of both the lake surface and the

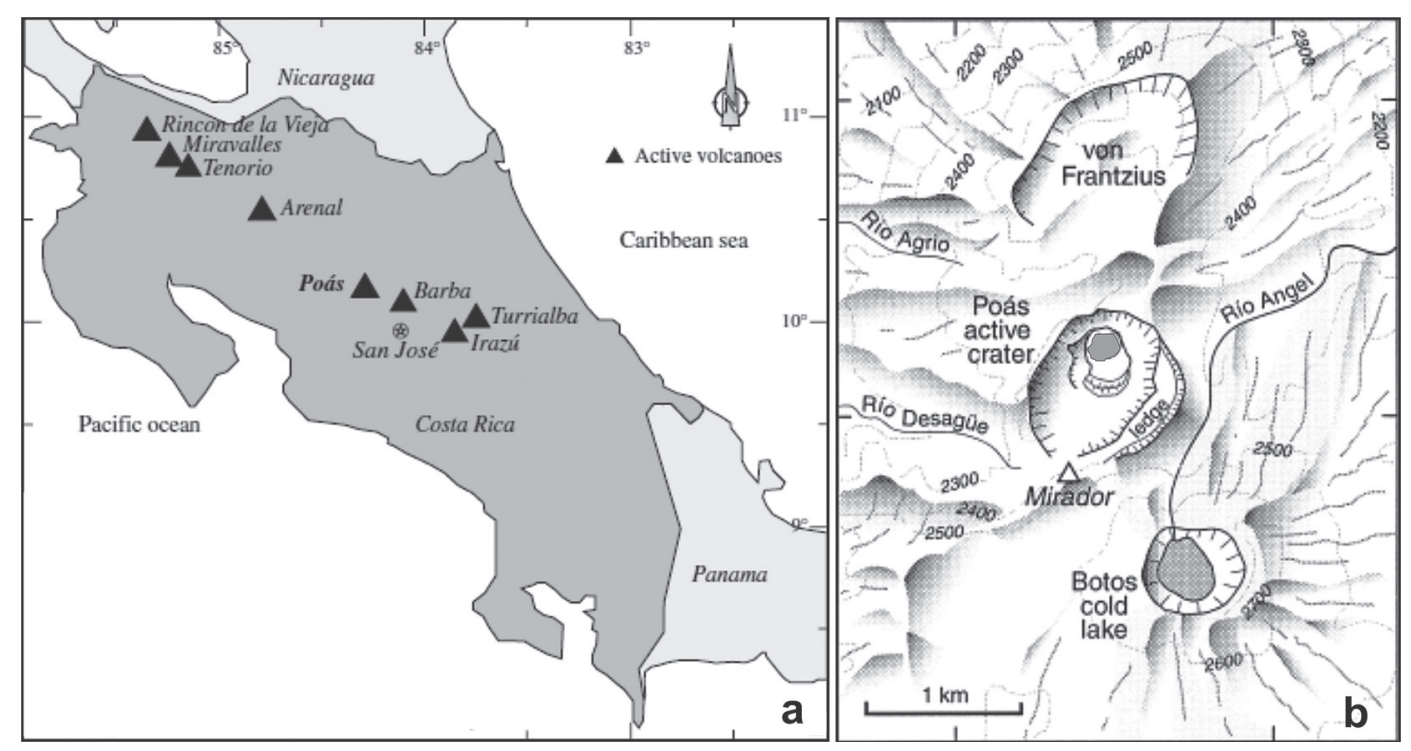

Fig. 1: (a) Map of Costa Rica. The black triangles identify active volcanoes (modified after Melián et al., 2007). (b) Map of Poás summit area with the three eruptive centres. In the centre is the presently active crater of which the grey portion is the lake (modified after Rymer et al., 2000). 
dome fumaroles were recorded using a P25 handheld infrared thermal camera manufactured by Forward Looking InfraRed (FLIR) Systems. The optics provide a $24 \times 18^{\circ}$ field-of-view (FOV) and direct radiation on to a $320 \times 240$ uncooledmicrobolometer detector array sensitive in the $7.5-13 \mu \mathrm{m}$ waveband. Its quoted precision is $\pm 2 \%$ (or $\pm 2^{\circ} \mathrm{C}$ ) and the thermal sensitivity is $0.08^{\circ} \mathrm{C}$ at $30^{\circ} \mathrm{C}$. The camera can record in several temperature ranges and at different sampling rates. For the measurements, we used the $0-500^{\circ} \mathrm{C}$ range and a time step of $10 \mathrm{~s}$. The thermal camera was tripodmounted so as to gather sequences of comparable images from different locations (Fig. 2). The dome was imaged from a frontal view (from the northern crater rim) at a mean distance of $\sim 400$ $\mathrm{m}$, resulting in a mean target pixel size of $\sim 0.55$ $\mathrm{m}$, whereas the lake surface was taken from the eastern crater rim from a distance of $\sim 200 \mathrm{~m}$ from the lake centre giving a mean pixel size of $\sim 0.28$ $\mathrm{m}$. To provide greater spatial resolution while imaging the dome's fumaroles, an additional 12 $\times 9^{\circ}$ lens with focal length of $72 \mathrm{~mm}$ was used. The additional lens reduced the target pixel size to $\sim 0.26 \mathrm{~m}$. Measurements were made between 16:40 and 20:18 UT (all times are given in UT) on the 17th and between 15:00 and 18:40 on 18 March 2009. To make a first-order compensation of the detected radiance for atmospheric attenuation, the measured air temperature (Tamb), relative humidity (RH) and path length, were entered together with an estimate of surface emissivity of the target into the camera software for internal modelling. Following Harris and Maciejewski (2000), we used emissivity of 0.97 to track temperature variations at the dome fumaroles, and, in agreement with Salisbury \& D'Aria (1992) and Hernández et al. (2007), emissivity of 0.96 for imaging of the lake surface. Tamb and RH were measured using a portable atmospheric parameter sensor at the start and end of the acquisition.

Results are affected by oblique viewing geometry (Dehn et al., 2002; Ball \& Pinkerton, 2006), volcanic gas absorbance (Calvari et al., 2004; Sawyer \& Burton, 2006), and solar reflection and heating (Francis, 1979; Calvari \& Pinkerton, 2004). Oblique geometry represents a crucial issue while retrieving pixel-integrated temperature as emissivity varies according to the viewing angle (Ball \& Pinkerton, 2006). However, while carrying out ground-based measurements, it is often not possible to capture nadir images of the hot targeted feature. In our case, the ground-based sites from which we took images, prevented us from collecting the lake surface from nadir, thus results presented here have to be considered as minimum values. In order to minimise the effects of volcanic gas absorption, we collected data out of the volcanic plume, from the crater flank opposite and perpendicularly to the plume spreading direction. We were not able to carry out either long time acquisition or pre-dawn imaging, so the solar effects were not constrained, but assumed to be small.

Additionally, considering the dimensions of fumaroles (commonly varying from centimetres to metres) and the calculated target pixel size, while imaging the dome, we have also taken into account the problem posed by pixel thermal heterogeneity (Dozier, 1981). In fact, due to the impossibility of measuring directly the actual area covered by fumaroles, and thus to exclude the contribution of the background (heated portions of the dome which are vent-free) within pixels, we preferred to observe the variability of apparent temperature averaged over selected Regions Of Interest (ROIs; e.g., Harris et al., 2009). Uncertainties affecting thermal imaging are detailed in Spampinato et al. (in review). Visible images (photographs) were recorded at the same time as the thermal imagery.

\section{$\mathrm{SO}_{2}$ Flux Measurements}

$\mathrm{SO}_{2}$ flux traverses were performed using an Ocean Optics USB2000 ultraviolet spectrometer with $\sim 1.1 \mathrm{~nm}$ (FWHM) spectral resolution in the 294-373 nm range. Depending on the available light intensity, individual spectra were recorded for exposure times varying between 80 and $100 \mathrm{~ms}$. Up to 50-60 individual spectra were composited to maximize the signal-to-noise ratio, whilst avoiding saturation in the spectral fitting region of interest. Sulphur dioxide column amounts were evaluated following the standard DOAS methodology 


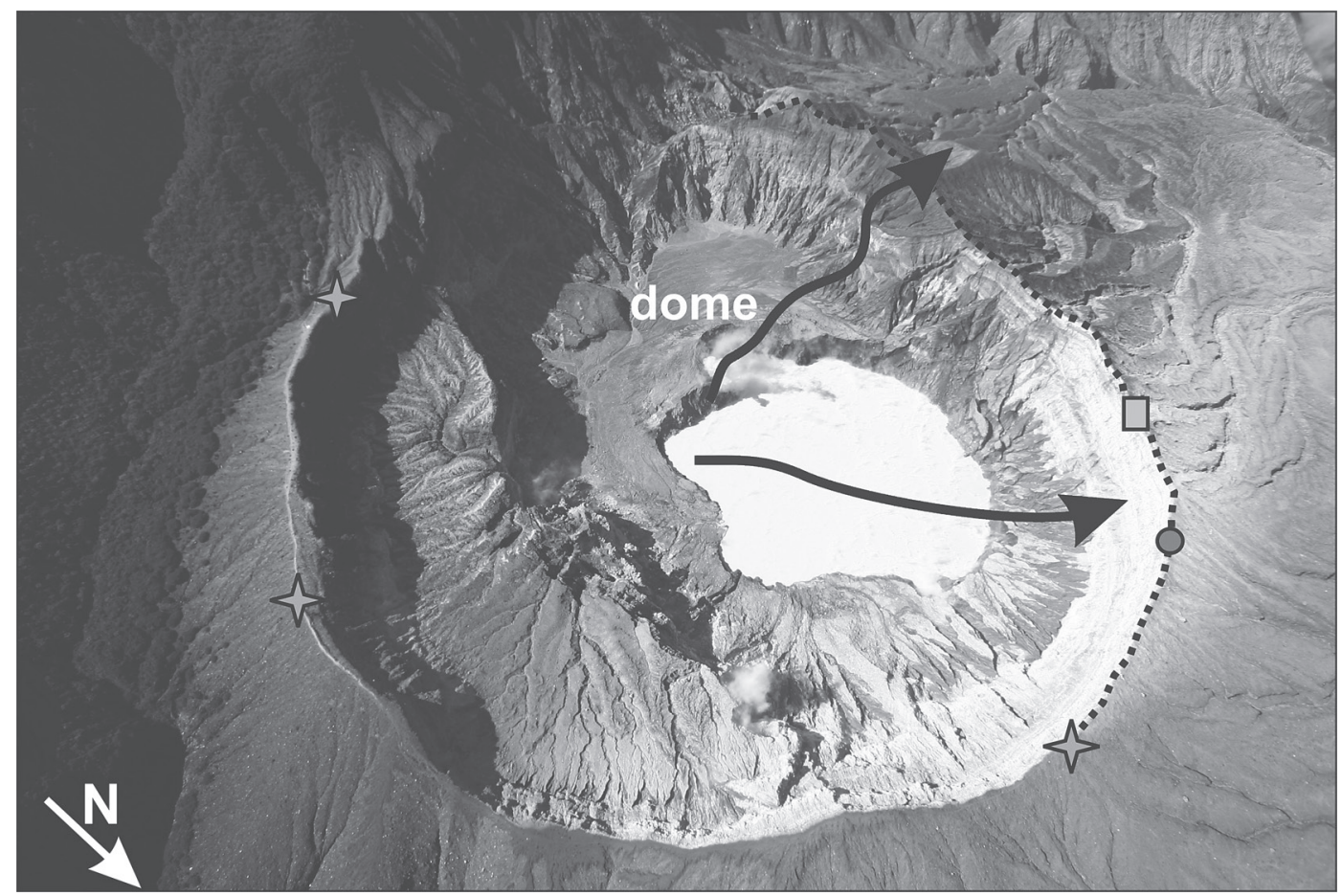

Fig. 2: Photo of Poás active crater (Laguna Caliente) taken in January 2006 during an airborne survey. The stars, the dot, and the rectangle show the locations from which thermal imaging, FTIR measurements, and filter pack sampling were made, respectively. The black-dotted line indicates the traverse route used to measure $\mathrm{SO}_{2}$ flux. The arrows indicate the prevalent plume dispersion from both the dome and the lake during our campaign.

(e.g., Noxon, 1975; Perner \& Platt, 1979; Platt \& Stutz, 2008) using the WinDOAS V2.10 software package (Fayt \& Roozendael, 2001). The ring spectrum (e.g., Solomon et al., 1987; Fish \& Jones, 1995) was calculated from the clear skyspectrum (spectrum collected out of the plume) following the approach of Chance (1998). Both laboratory spectra of $\mathrm{SO}_{2}$ and $\mathrm{O}_{3}$ (Vandaele et al., 1994; Malicet et al., 1995) and the Ring spectrum were convolved to the spectrometer's resolution. The optimal fitting window (306.5-320.0 nm) was found by obtaining near random fit residual structures with minimal standard deviation.

Three downwind traverses were made following the walking-based method described by McGonigle et al. (2002). Observations were gathered between 16:40 and 18:10, and 15:12 and 16:30 on 17 and 18 March 2009, respectively. The route followed a crude path on the north and west rim of the crater (Fig. 2). Each traverse took around 30-45 min. Wind speed was measured every $10 \mathrm{~min}$ using a portable anemometer indicating mean values of $\sim 3 \mathrm{~m} \mathrm{~s}^{-1}$. A GPS receiver logged geographic position continuously (to locate each recorded spectrum). Errors on the $\mathrm{SO}_{2}$ mass flux depend mainly on the large uncertainty in plume-wind speed estimation (e.g., Doukas, 2002; Mather et al., 2006; Williams-Jones et al., 2008). Stoiber et al. (1983) calculated uncertainty in flux calculation between 10 and $40 \%$.

\section{Fourier Transform InfraRed Measurements}

Active open-path FTIR spectroscopic measurements were made on the north-western crater rim on 18 March 2009 (Fig. 2). A total of 400 spectra were collected between 16:02 and 16:35 using a portable spectrometer manufactured by MIDAC Corporation. The spectrometer was 
equipped with a stirling-cooled MCT detector (sensitive between 600 and $5000 \mathrm{~cm}^{-1}$ ) and was working at $0.5 \mathrm{~cm}^{-1}$ resolution. A 5-inch artificial lamp provided the source of infrared radiation, and was positioned on the crater rim, $120 \mathrm{~m}$ from the spectrometer (close to the rectangle in Fig. 2 ). Given the location and the prevailing wind pattern, it is likely that we mostly measured gas emitted from the crater lake, with a very minor contribution from the dome.

Spectra were analysed using a code written by M. Burton (e.g., Burton et al., 2003). First, spectra were simulated via a radiative transfer forward model (the Reference Forward Model; Edwards \& Dudhia, 1996), together with line parameter data from the HITRAN database (Rothman et al., 2005) using estimates for pressure $(728 \mathrm{hPa})$, temperature $\left(17^{\circ} \mathrm{C}\right)$ and initial column amounts, specified for both volcanic and atmospheric gases. The best fits to measured spectra were then found using an optimal estimation, nonlinear least-square algorithm (Rodgers, 1976). For each spectrum we retrieved column amounts of $\mathrm{H}_{2} \mathrm{O}$ and $\mathrm{CO}_{2}$ (between 2100 and $2240 \mathrm{~cm}^{-1}$ ) and $\mathrm{SO}_{2}$ (between 2450-2540 $\mathrm{cm}^{-1}$ ). Error estimates for the fits are calculated as part of the retrieval procedure based on the standard deviation of the residual across the chosen spectral window. For measurements presented here the errors were between 5 and $10 \%$.

\section{Filter Packs}

The plume from the crater lake was also sampled (at the site indicated in Fig. 2) using filter packs (e.g., Allen et al., 2000) pumped at 18

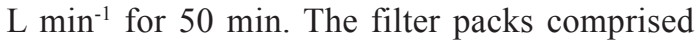
of a particle filter (Millipore, $47 \mathrm{~mm}$, AAWP, pore size $0.8 \mathrm{~mm}$ ) followed by three alkalitreated filters to collect acidic gases (Whatman 41 ashless circles impregnated with $5 \% \mathrm{~K}_{2} \mathrm{CO}_{3}$ and $1 \%$ glycerol in distilled deionised water). In total, three filter pack samples were collected. Following sampling, each of them was immediately sealed inside a large PTFE bag and then transferred into individual PTFE bags. The filters were analysed by extraction into distilled deionised water for $24 \mathrm{~h}$, followed by DIONEX ion chromatography (e.g., Mather et al., 2006; Martin et al., 2008) for anions $\left(\mathrm{SO}_{4}^{2-}, \mathrm{Cl}^{-}, \mathrm{F}^{-}, \mathrm{Br}\right.$, $\left.\mathrm{NO}_{3}^{-}\right)$and cations $\left(\mathrm{Na}^{+}, \mathrm{K}^{+}, \mathrm{Ca}^{2+}, \mathrm{Mg}^{2+}, \mathrm{NH}_{4}^{+}\right)$. Several field blanks were extracted and analysed similarly to allow for blank correction. Analysis of the calibration standards indicated errors $<10 \%$ in the determination of ion concentrations in solution. Additional errors (e.g., in flow rate, sampling duration and extraction efficiency) are negligible, so we estimate the total error on ion concentrations in the plume as $\sim 10 \%$.

\section{THERMAL AND VISUAL OBSERVATIONS}

The 17-18 March 2009 survey followed the magnitude 6.2 earthquake of 8 January 2009 (RSN, 2009; Ramírez et al., 2010). We observed significant morphological changes to the crater as a result of this seismic activity. Along the western rim, the damage of the pre-existing path and the opened fractures roughly concave towards the crater centre, suggested rim collapse within the inner crater and instability of the flanks.

The crater activity consisted of intense fumarolic degassing from the north side of the dome, which combined with elevated air relative humidity (between 50 and $80 \%$ on 17 , and 40 to $60 \%$ on 18), was producing a dense white plume carried by the wind towards the south-western flank of the crater (Fig. 2 and Fig. 3a). Degassing was from numerous fumaroles, the largest and most active of which were clustered on the lower portion of the dome (Figs. 3b, c). The dome surface appeared brittle and cracked with debris accumulated along its flanks (Fig. 3b). Areas affected by intense degassing appeared yellow due to sulphur deposition around the active fumaroles.

The lake had a whitish colouration (Fig. 3a) and was the site of diffuse degassing (Fig. 3d). The fumes were transported by the wind and crossed the lake from ESE-WNW giving the impression that the whole water mass was moving in the same direction (Fig. 3d). In the middle of the lake, a dark ellipse and brownish bands were observed (Fig. 3a). These consisted of muddy emissions from the lake bottom likely 
due to the degassing of either a single vent or a cluster of vents. Previous observations reported that these features result from convective movements (Rymer et al., 2005). The convective cell location likely corresponds to the site from which the small 12 January 2009 phreatic-eruption occurred. Mud stretched roughly northwards, developing well-marked darkish strings across the lake surface, which curved gradually according to the wind direction (Fig. 3a). The northward direction may have corresponded to the real motion of the lake water mass.

Thermal imagery of the whole crater taken from the tourist viewpoint on the southern rim revealed two thermal anomalies sited in the ENE inner flank (Fig. 4). The topographically elevated anomaly showed apparent temperatures slightly higher than the other with maximum values of $\sim 42^{\circ} \mathrm{C}$ compared to the $\sim 36^{\circ} \mathrm{C}$ recorded at the lower anomaly.

In addition, thermal images highlighted several cracks in the southern floor of the crater just behind the dome. These were curved towards the crater bottom (Fig. 4).

\section{RESULTS AND DISCUSSION}

\section{Thermal Imagery}

To analyse thermal imagery of the dome we defined 5 main ROIs (Fig. 5a), which included the hottest fumaroles (following Harris et al., 2009). Estimated ROIs' areas varied from $\sim 20$ to $60 \mathrm{~m}^{2}$. For each ROI, we derived the mean apparent temperatures, which varied between $\sim 25$ and $40^{\circ} \mathrm{C}$; the highest values were recorded at ROI 1 (Fig. $5 b)$. This maximum value results from the combination of the targeted fumarole activity and the smaller size of the fixed area (i.e. $\sim 20 \mathrm{~m}^{2}$ ) with respect to those of ROIs 2-5. The high-frequency variations in the trend of the five ROIs, are due mainly to the variable wind velocity and quantity of volcanic gas passing through the line of sight of the thermal camera. This is more evident in the case of ROI 5, which owing to the viewing geometry was more susceptible to these variations. The low-frequency negative fluctuations result from changes in the atmospheric conditions, and especially to increases in relative humidity during our measurement period (Fig. 5b).

Maximum apparent temperatures recorded were $80^{\circ} \mathrm{C}$. Although the calculated values represent temperature averaged over the ROIs' areas, and thus are not comparable with kinetic temperatures obtained through direct measurements $\left(\sim 90^{\circ} \mathrm{C}\right.$ measured in December 2008 ; Mora et al., 2008), the low values recorded agree at least with the general declining trend recorded since the 1981 eruptive crisis when temperatures at the dome fumaroles decreased from $\sim 1000^{\circ} \mathrm{C}$ to $<100^{\circ} \mathrm{C}$ by 1989 (e.g., Rowe et al., 1992b). According to high-resolution gravimetric data such low temperatures are consistent with the cooling and crystallisation of a shallow magma intrusion (Fournier et al., 2004).

The study of crater lakes provides information on the activity of the shallow magma intrusion beneath them. They reflect the dynamics of heat and chemical and mass transfer from the entrapped magma body, thus providing information on the amount of heat flowing out of the shallow volcanic system (Trunk \& Bernard, 2008). Hot, acidic crater lakes can be found in several volcanic environments, and their longevity has been attributed to the continuous replenishment by both magmatic (hydrothermal fluids) and non-volcanic (e.g., rainfall water) sources associated to low permeability of the lake bottom (Brown et al., 1989; Oppenheimer, 1993). Heat coming from the underlying magma intrusion is transferred in the water mass essentially by convection, which involves loss of enthalpy from the rising magmatic fluids (Brown et al, 1989). Hence, the temperature of a crater lake reflects the interaction between magma at depth and the volcanic hydrothermal system, and can thus be used for monitoring purposes. At several volcanoes, increases in crater lake temperatures preceded eruptive crises (e.g., Brown et al., 1989, 1991; Oppenheimer, 1993; Ohba et al., 2000; Varekamp et al., 2001).

Crater lake temperature measurements have been commonly carried out using in situ thermometers (e.g. Mora et al.; 2004, Ramírez et al., 2010), and satellite imagery (e.g., Oppenheimer, 1993). Recently, Hernández et al. (2007) used 


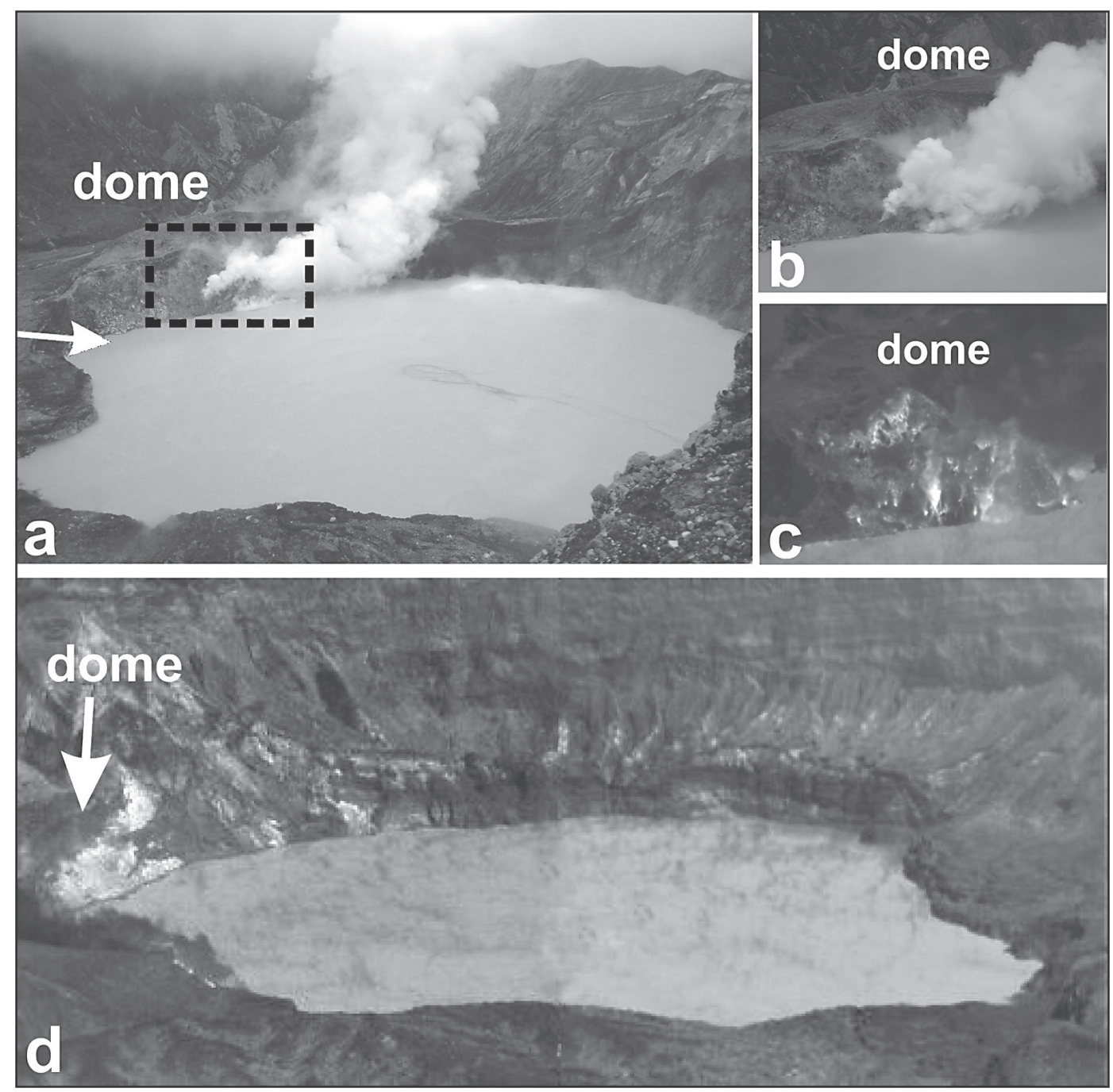

Fig. 3: (a) Photo of Poás crater lake taken on 17 March 2009 from the NNW. The black-dashed square shows the area imaged in (b) and (c), and the white arrow the direction from which (d) was recorded. Note the darkish streaks in middle of the lake. (b) and (c) visible and thermal images of the dome taken on 17 March 2009 from the NNW. In the thermal image, whiter is hotter. (d) Mosaic of two thermal images capturing the whole crater lake (viewed from the SE).

a hand-held thermal camera for assessing the thermal activity of Santa Ana crater lake in El Salvador. During our survey at Poás volcano, the thermal camera FOV and the path length prevented us from capturing the whole Laguna Caliente lake within a single image, therefore we analysed separately the area of the lake near the dome (Fig. 6a; mean path length of $\sim 225 \mathrm{~m}$ ) and the distal zone (Fig. 6b, mean path length $\sim 275$ $\mathrm{m})$. It is noteworthy that while measuring water lake temperatures using infrared radiometers, it is necessary to consider the 'skin effect' produced by vertical heat flux at the air-water boundary (Oppenheimer, 1997). In fact, heat loss through the surface, triggered either by free or forced convection produces a temperature decrease along the water column. Thus, apparent temperatures are representative just of the top $0.1 \mathrm{~mm}$ of water (skin temperature) and not of the 'bulk surface' temperature of the water mass (Robinson et al., 


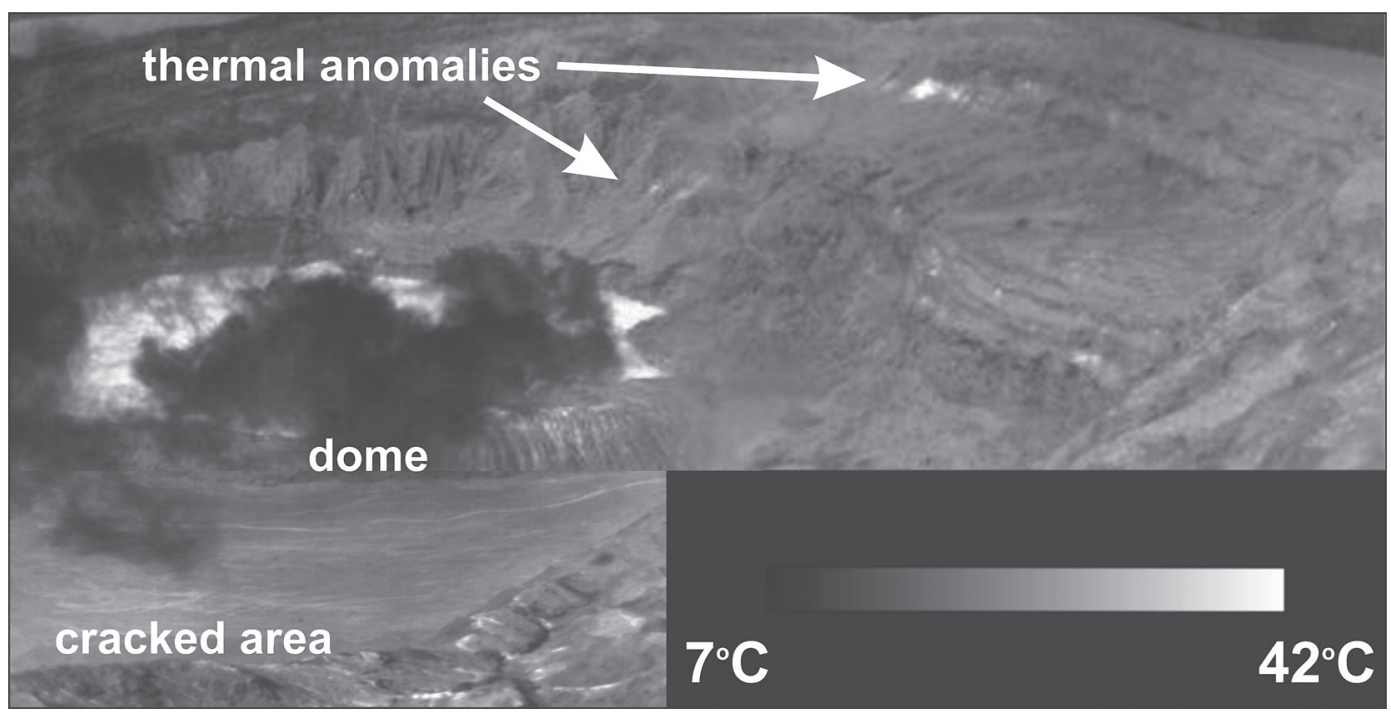

Fig. 4: Thermal image of Poás inner crater showing the lake, the degassing dome, the morphology of the crater inner flanks, the two thermal anomalies recorded on the ENE inner slope of the crater, and a fractured area behind the dome. The figure is a collage of three thermal images taken on 17 March 2009 from S (see Fig. 1).

1984; Oppenheimer, 1997; Trunk \& Bernard, 2008). Due to the last seismic event, which damaged the crater rim, we could not approach the lake surface for direct temperature measurements for calibrating the radiometrically-derived data. Hence, the following apparent temperatures and lake thermal profile reported refer to minimum values (see section 2.1) of the lake skin.

Mean apparent temperatures of the lake skin were recorded on 18 March 2009 between 15:00 and 15:26 (a) and 15:28 and 15:53 (b); these vary from $30-35^{\circ} \mathrm{C}$ (a) and from $30-34^{\circ} \mathrm{C}$ (b) showing an almost uniform thermal behaviour of the lake skin.
Minimum and maximum temperatures recorded at the proximal and distal area of the lake varied between $20-48^{\circ} \mathrm{C}$ and $13-36^{\circ} \mathrm{C}$, respectively. Despite the skin effect, maximum values are similar to the $\sim 40^{\circ} \mathrm{C}$ measured in situ between January and March 2009 (Mora et al., 2008; Ramírez et al., 2010), as well as to the $\sim 40-60^{\circ} \mathrm{C}$ previously recorded by Oppenheimer (1993) by satellite imagery. According to Mora et al. (2007), low temperatures are typical of the volcano in a non-eruptive state. Note that thermal imagery-retrieved temperatures are not straightforwardly comparable with field data, as temperatures derived by the

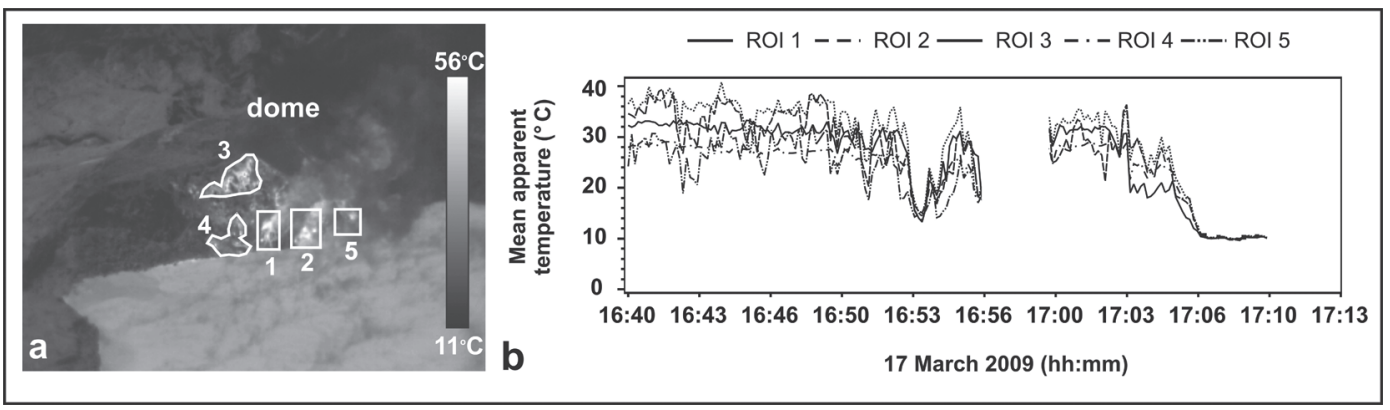

Fig. 5: (a) Thermal image recorded on 17 March 2009 from NNW showing the five ROIs corresponding to the hottest and most vigorously degassing fumaroles. (b) Plot of the mean apparent temperatures retrieved for each of the five ROIs for the longest time series (recorded between 16:40 and 17:10 UT). 

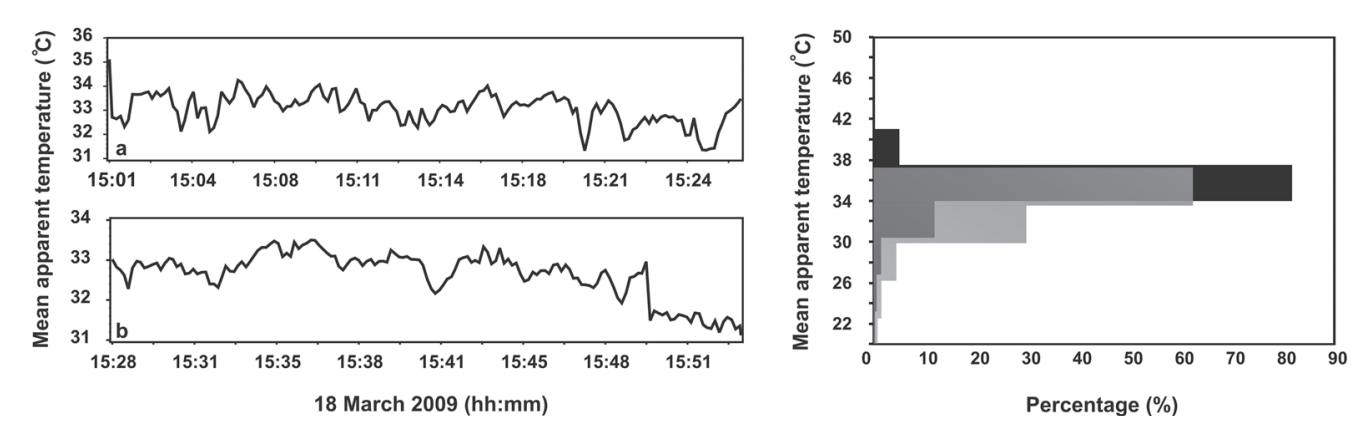

Fig. 6: On the left, mean apparent temperature variability for the lake area close to the dome (a) and for the distal area (b), respectively, taken on 18 March from the SE (see Fig. 3d). On the right, histograms showing the corresponding frequency distributions of apparent temperatures for the proximal (in black) and distal (in grey) areas. Data extracted from a pair of images (for proximal and distal areas of the lake) chosen as representative of the lake activity on 18 March.

former represent the thermally emitted radiation from the lake skin, whereas field measurements provide bulk temperatures at a given site and a given water column depth. As we observed for dome fumaroles, negative peaks in the time series (Fig. 6) result from the action of the wind and atmospheric conditions.

The histogram contained in Figure 6 shows the area-weighted frequency distributions of the mean apparent temperature of the proximal area of the lake (black) and of the distal (grey). Despite the oblique imagery, thermal imaging offers the great advantage of providing surface temperature distribution, which might be more representative of the lake thermodynamics with respect to a bulk sampling representative of just a spot (Oppenheimer, 1993). The histograms were derived from selected thermal images according to the highest mean temperature values and the lowest standard deviations (Chiodini et al., 2007). The comparison between the black and grey temperature distributions reveals that when moving further from the dome (hot fumaroles) the unimodal distribution of apparent temperature migrates towards lower values.

Figure 7 shows the thermal profile of the crater lake skin along a S-N direction (see Fig. 3d). Except for the first part of the signal (grey rectangle), where the attenuation of the detected radiance by the dome plume produces apparent temperature lowering (between $\sim 15$ and $32^{\circ} \mathrm{C}$ ), temperatures are close to the mean value of $34^{\circ} \mathrm{C}$. The relatively stable thermal profile trend is in agreement with the $1.4^{\circ} \mathrm{C}$ variation across the lake measured by Neshyba et al. (1988) during in situ surveys.

\section{$\mathrm{SO}_{2}$ Flux}

The $\mathrm{SO}_{2}$ fluxes determined from the three walking traverses were 86,70 , and $73 \mathrm{Mg} \mathrm{d}^{-1}$. The mean emission rate was $76 \pm 9 \mathrm{Mg} \mathrm{d}^{-1}$ (error is \pm one sigma). This is consistent with $\mathrm{SO}_{2}$ flux observations since 1991 (Fig. 8; Andres et al., 1992; Zimmer et al., 2004; Barrancos et al., 2008).

The overall low sulphur emission may reflect a decrease of activity after the vigorous volcanic phases observed in the 1980s (e.g., Martínez et al., 2000), when high fluxes ( $\sim 8$ times greater than those recorded starting from the 1990s) were documented (Casadevall et al., 1984; Stoiber et al., 1986; Andres et al., 1992; Zimmer et al., 2004). For small plumes, walking-based traverses allow for more detailed recording of volcano degassing signatures. During our campaign, we were able to discriminate between the $\mathrm{SO}_{2}$ emitted from the lake and the $\mathrm{SO}_{2}$ from the dome. We estimated that both gas sources contributed roughly in equal proportions to the overall mean $\mathrm{SO}_{2}$ flux (76 $\mathrm{Mg} \mathrm{d}^{-1}$; Fig. 9). As suggested by Vaselli et al. (2003), the lake $\mathrm{SO}_{2}$ flux, similar to that emitted by the dome, might result from poor efficiency of the shallow hydrothermal system in condensing magmatic components, i.e. $\mathrm{SO}_{2}$ and $\mathrm{HCl}$, promoting vigorous sulphur release. 


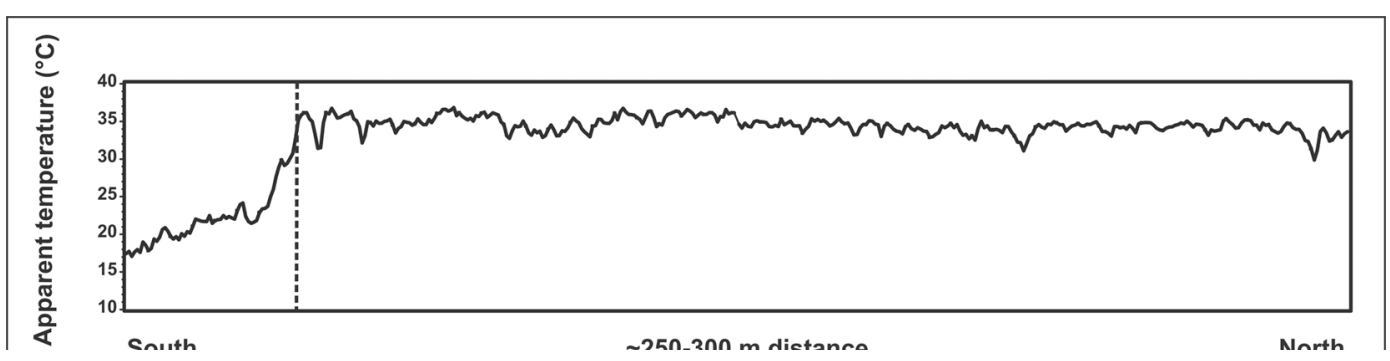

Fig. 7: N-S thermal profile of the crater lake skin (see Fig. 3d). Apparent temperatures cluster around $34^{\circ} \mathrm{C}$. Lower temperatures from $\sim 15$ to $32^{\circ} \mathrm{C}$ (black-dotted line) result from the dome plume absorbing the thermal radiance emitted by the lake (Sawyer \& Burton, 2006).

\section{Gas composition measured by FTIR spectroscopy}

Plots of $\mathrm{H}_{2} \mathrm{O}$ vs. $\mathrm{SO}_{2}$ and $\mathrm{CO}_{2}$ vs. $\mathrm{SO}_{2}$ are shown in Figure 10. The y-intercepts obtained from linear regression of the data in Figures 10a and 10b represent the ambient atmospheric component of $\mathrm{H}_{2} \mathrm{O}$ and $\mathrm{CO}_{2}$, respectively. The gradients of the linear regression lines represent the molar ratios of $\mathrm{H}_{2} \mathrm{O} / \mathrm{SO}_{2}$ and $\mathrm{CO}_{2} / \mathrm{SO}_{2}$ in the volcanic plume. We obtain molar ratios of $\mathrm{H}_{2} \mathrm{O} / \mathrm{SO}_{2}=151$ and $\mathrm{CO}_{2} /$ $\mathrm{SO}_{2}=1.56$. It should be noted that the $\mathrm{H}_{2} \mathrm{O}$ intercept of $2.5 \times 10^{21}$ molecules $\mathrm{cm}^{-2}$ in Figure $10 \mathrm{a}$ corresponds to an atmospheric RH of $43 \%$, which is in close agreement with independent RH measurements taken throughout the FTIR observation period (40 to $50 \%$ ). In addition, the $\mathrm{CO}_{2}$ intercept of $8.4 \times 10^{19}$ molecules $\mathrm{cm}^{-2}$ in Figure $10 \mathrm{~b}$ corresponds to an atmospheric mixing ratio of $386 \mathrm{ppm}$. This value is in excellent agreement with measurements of global atmospheric concentrations of this gas species made during March 2009 (388 ppm; data from P. Tans, NOAA/ESRL).

$\mathrm{HCl}$ and $\mathrm{HF}$ gases (normally retrievable in FTIR spectra between $\sim 2690$ and $2830 \mathrm{~cm}^{-1}$, and $\sim 4070$ and $4210 \mathrm{~cm}^{-1}$, respectively; Sawyer et al., 2008) were not detected here. Under the measurement conditions described, we estimate detection limits of $5 \times 10^{16}$ molecules $\mathrm{cm}^{-2}$ and $1 \times 10^{16} \mathrm{~mol}-$ ecules $\mathrm{cm}^{-2}$, respectively, for these species. Based on the maximum column amount of $\mathrm{SO}_{2}\left(2.0 \times 10^{18}\right.$ molecules $\mathrm{cm}^{-2}$ ), we calculate that $\mathrm{SO}_{2} / \mathrm{HCl}$ and $\mathrm{SO}_{2} / \mathrm{HF}$ molar ratios in emissions from the crater lake must be greater than 40 and 200, respectively.

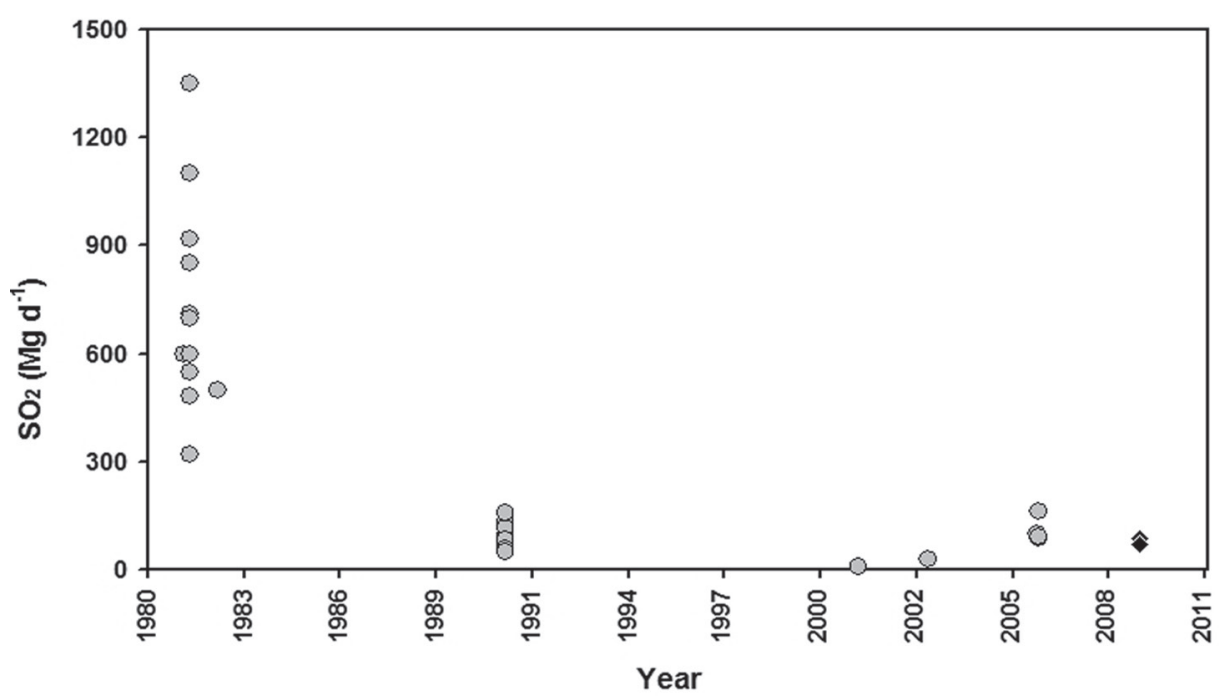

Fig. 8: The $\mathrm{SO}_{2}$ flux emission record since 1981. Results from individual traverses and daily means taken from Andres et al. (1992), Casadevall et al. (1984), Stoiber et al. (1986), Zimmer et al. (2004), Barrancos et al. (2006) and this work (black diamonds) are shown. 


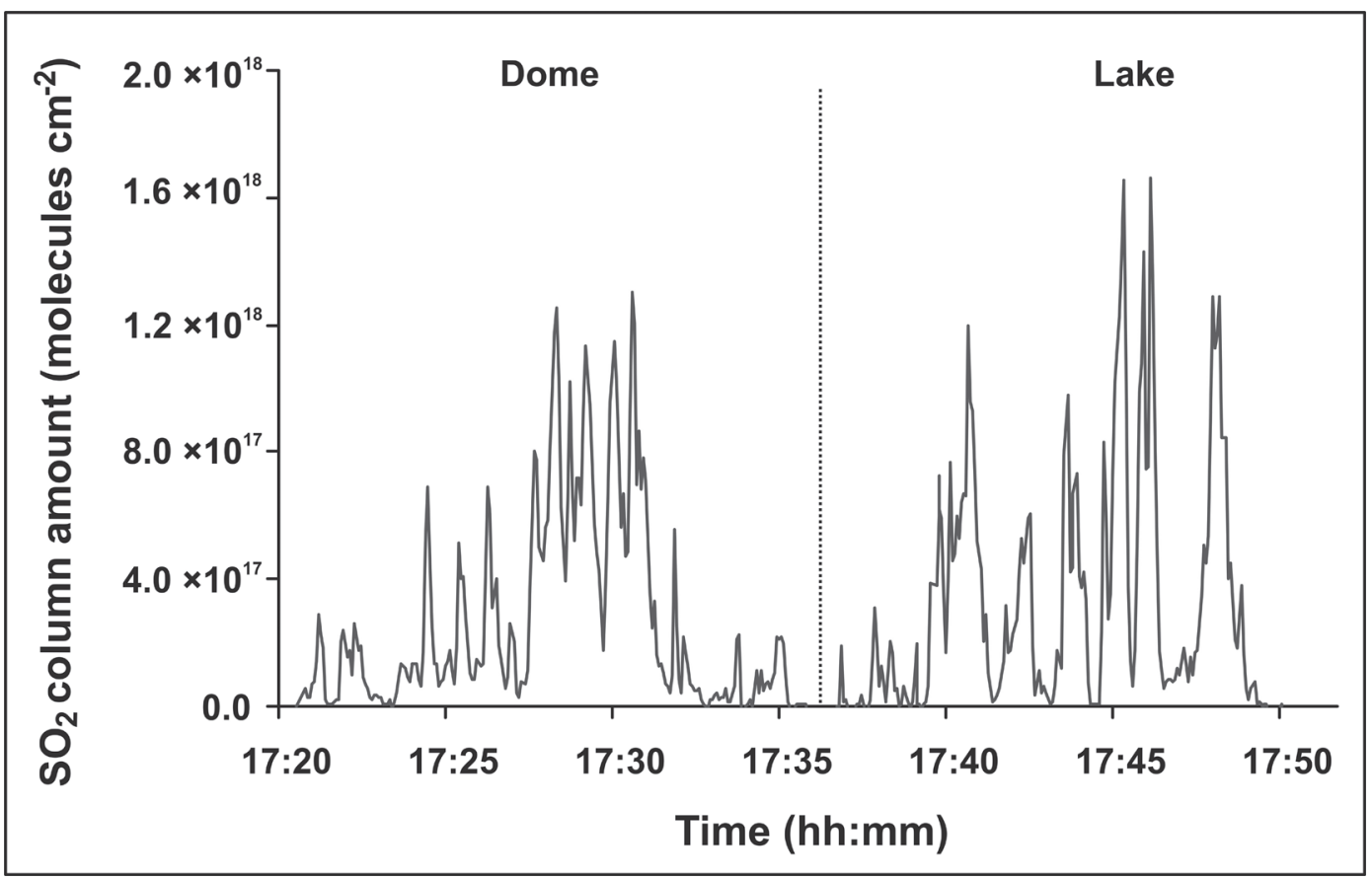

Fig. 9: $\mathrm{SO}_{2}$ column amount vs. time on traverse performed on 17 March 2009. By performing walking-based traverse, it was possible to discriminate between the gas contribution from both the dome and the lake in the bulk $\mathrm{SO}_{2}$ flux. The two gas sources contributed similarly to the total $\mathrm{SO}_{2}$ flux emitted by the crater ( $48 \%$ and $52 \%$, respectively).

Table 1 gives a summary of some previous analyses of Poás fumarole samples. There is a high degree of variability within these datasets likely due to the difference in the methodology of data collection (sampling from single fumaroles and from the bulk lake plume) and analysis. Although the discrepancies, our FTIR crater lake ratios lie within the ranges recorded for low temperature fumaroles (Table 1).

\section{Filter packs}

Several ions were detected in the particle phase (Table 2), in levels exceeding regional atmospheric background levels (Mather et al., 2006). The most abundant ions were consistently $\mathrm{K}^{+}$and $\mathrm{SO}_{4}^{2-}$, with smaller amounts of $\mathrm{Ca}^{2+}, \mathrm{Cl}^{-}$ and $\mathrm{Mg}^{2+}$. However, the ratios between elements were quite variable, especially between samples collected on different days (i.e., samples 1A and 1B on 17 March, and sample 2 on 18 March), sug- gesting varying contributions from several emission sources e.g., lake, the dome, and fumaroles on the crater walls. Brantley et al. (1987) give the lake water and fumarolic gas composition as being richer in $\mathrm{Ca}^{2+}$ than $\mathrm{K}^{+}$, which is opposite to the trend found in the particles. Hence, the abundance of $\mathrm{K}^{+}$cannot be explained simply by condensation of fumarolic gases or by a spray (from bursting bubbles) at the lake surface. One possibility is that chemical fractionation occurs as bubbles burst on the surface of the lake such that the spray has a composition distinct from the lake's (e.g., Duce \& Hoffmann, 1976). In any case, we note that these preliminary results are at least consistent with those of Pfeffer et al. (2006), who identified several individual particles at Poás with $\mathrm{K}^{+}>\mathrm{Ca}^{2+}$ (using TEM-EDX). No acidic gas species were observed above detection limits. The emissions from open-vent volcanoes (e.g., Masaya, Nicaragua) typically show a $\mathrm{SO}_{2} / \mathrm{SO}_{4}^{2-}$ molar ratio of $\sim 100$ (e.g., Martin et al., 2010). Applying the same ratio to the mean $\mathrm{SO}^{2-}$ at Poás 

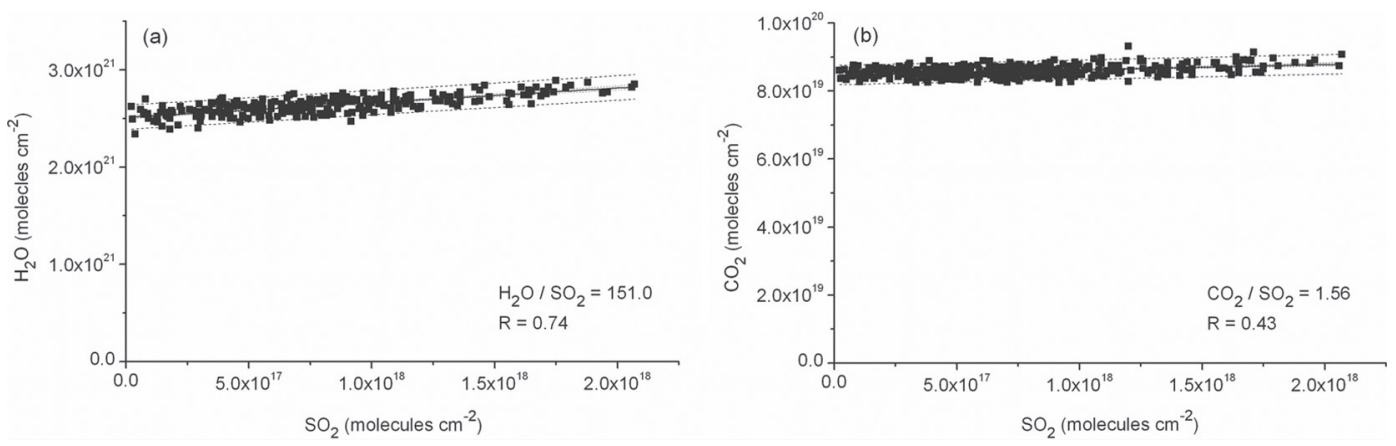

Fig. 10: Scatter plots of (a) $\mathrm{H}_{2} \mathrm{O}$ vs. $\mathrm{SO}_{2}$ and (b) $\mathrm{CO}_{2}$ vs. $\mathrm{SO}_{2}$ retrieved from FTIR spectra collected on 18 March 2009. The solid lines are linear regressions fitted to the data whilst the dashed and dotted lines represent prediction bands and $95 \%$ confidence limits of the regression, respectively.

would indicate $\mathrm{SO}_{2} \sim 1200 \mu \mathrm{mol} \mathrm{m}{ }^{-3}$ (equivalently, $30 \mathrm{ppm}$ ). This concentration would certainly be detectable so $\mathrm{SO}_{2} / \mathrm{SO}_{4}^{2-}$ must have been lower than typically found at open-vent volcanoes. We suggest that conversion of $\mathrm{SO}_{2}$ to $\mathrm{SO}_{4}^{2-}$ was promoted by oxidation reactions as the gases bubbled through the lake. A further complicating factor is that the alkali-treated filters had higher blank values than the particle filters. For future filter pack work at Poás, longer sampling times (>50 min) are recommended, ideally from within the crater to minimise atmospheric dilution.

\section{SUMMARY AND FUTURE PROSPECTS}

On 17 and 18 March 2009, we measured the temperature, gas composition and $\mathrm{SO}_{2}$ emission rates released from both the dome fumaroles and lake of Laguna Caliente crater of Poás volcano. Observations were made simultaneously using remote and ground-based techniques i.e. thermal imagery, UV and active FTIR spectroscopy, and filter packs. Temperatures measured at the lake surface and at areas of the dome sites of hot degassing were low. The $\mathrm{SO}_{2}$ flux contributions from the lake and dome were comparable. These results are consistent with the phase of modest volcanic activity of Poás observed since the 1990s. FTIR spectroscopic measurements showed that the composition of the gas emitted from the crater lake was within the ranges of analyses of low temperature fumaroles from 2003. However, there were greater proportions of $\mathrm{CO}_{2}$ and less $\mathrm{HCl}$ relative to $\mathrm{SO}_{2}$, compared to analyses of high temperature fumaroles from the early 1980s. Analysis of particle phases in the plume revealed variable contributions from distinct sources. Although the logistics and weather conditions precluded extended or pre-dawn observations, the integration of the diverse parameters has provided a multiparametric account of

Table 1

Discrepancies Ratios

\begin{tabular}{cccc}
\hline Reference & $\mathrm{H}_{2} \mathrm{O} / \mathrm{CO}_{2}$ & $\mathrm{CO}_{2} / \mathrm{SO}_{2}$ & $\mathrm{SO}_{2} / \mathrm{HCl}$ \\
\hline $\begin{array}{c}\text { Symonds et al., 1994 } \\
\text { (high temp. Fumaroles measured 1981, 1938) }\end{array}$ & 90 to 184 & 0,4 to 0,7 & $\sim 2$ \\
$\begin{array}{c}\text { 2003 IAVCEI field campaign } \\
\text { (low temp. fumaroles, } \sim 100^{\circ} \mathrm{C} \text { ) } \\
\text { FTIR data, this study }\end{array}$ & 16 to 124 & 0,5 to 2,5 & 1,9 to 113 \\
& 96,8 & 1,56 & $>40$ \\
\hline
\end{tabular}


Table 2

Ions detected in the particle phase

\begin{tabular}{cccccc}
\hline & $1 \mathrm{~A}$ & $1 \mathrm{~B}$ & 2 & Mean & $\mathrm{BG}$ \\
\hline $\mathrm{K}^{+}$ & 25,0 & 45,0 & 7,9 & 26,0 & 0,4 \\
$\mathrm{SO}_{4}^{2-}$ & 8,6 & 18,0 & 8,1 & 12,0 & 1,0 \\
$\mathrm{Ca}^{2+}$ & 6,5 & 9,0 & 4,8 & 7,0 & 0,4 \\
$\mathrm{Cl}^{-}$ & 2,1 & 4,5 & 3,8 & 3,5 & 1,4 \\
$\mathrm{Mg}^{2+}$ & 1,3 & 1,4 & 1,3 & 1,4 & 0,2 \\
\hline
\end{tabular}

$\mathrm{F}^{-}, \mathrm{Br}, \mathrm{NO}_{3}^{-}, \mathrm{Na}^{+}, \mathrm{NH}_{4}^{+}$were below detection in all samples. No background measurements were made in Costa Rica so background measurements from Nicaragua are repoduce here form comparision (Mather et al., 2006)

the plume geochemistry and temperature estimations. Our results provide a comprehensive overview of the volcano state following the January 2009 seismic and volcanic events, and the first FTIR measurements carried out at this volcano. Based on this preliminary campaign, future measurements using the same monitoring techniques may include longer acquisition periods focused on the constraint of weather and diurnal effects on measurements. This combined with more frequent surveys and with the comparison and integration with in situ temperature and gas sampling might allow the discrimination between baseline activity levels useful for volcano surveillance.

\section{ACKNOWLEDGEMENTS}

This research was supported by the UK Natural Environment Research Council (NERC grant NE/F004222/1) and the NERC Field Spectroscopy Facility. GMS acknowledges VOLGASPEC project ANR-06-CATT-012-01 1122, RSM thanks Christ's College of Cambridge for financial support, and $\mathrm{CO}$ acknowledges further support from the NERC via the National Centre for Earth Observation. Mike Burton kindly provided the FTIR retrieval code. Mora-Amador R. \& Alvarado G.E. are kindly thanked for their detailed reviews. The Poás Volcano National Park for the permits and collaboration on the field.

\section{REFERENCES}

ALLEN, A.G., BAXTER, P.J. \& OTTLEY, C.J., 2000: Gas and particle emissions from Soufrière Hills Volcano, Montserrat, West Indies: Characterization and health hazard assessment.- Bull. Volcanol. 62: 8-19.

ANDRES, R.J., BARQUERO, J. \& ROSE, W.I., 1992: New measurements of $\mathrm{SO}_{2}$ flux at Poás volcano, Costa Rica.- J. Volcanol. Geotherm. Res. 49: 175-177.

BALL, M. \& PINKERTON, H., 2006: Factors affecting the accuracy of thermal imaging cameras in volcanology.- J. Geophys. Res. 111. DOI: $10.1029 / 2005 J B 003829$.

BARRANCOS, J., ROSELLÓ J.I., CALVO, D., PADRÓN, E., MELIÁN, E., HERNÁNDEZ P.A., PÉREZ, N.M., MILLÁN, M.M. \& GALLE, B., 2008: $\mathrm{SO}_{2}$ Emission from Active Volcanoes Measured Simultaneously by COSPEC and mini-DOAS.- Pure Appl. Geophys. 165: 115-133.

BRANTLEY, S.L., BORGIATT, A., ROWE, G., FERNÁNDEZ, J.F. \& REYNOLDS, J.R., 1987: Poás volcano crater lake acts as a condenser for acid metal-rich brine.Nature, 330: 470-472.

BROWN, G., DOWDEN, J., KAPADIA, P., STEVENSON, D., BARQUERO, J. \& MORALES, L., 1989: Energy budget analysis for Poás Crater Lake: Implications for predicting volcanic activity.- Nature, 339: 370-373.

BROWN, G.C., RYMER, H. \& STEVENSON, D., 1991. Volcano monitoring by microgravity and energy budget analysis.- J. Geol. Soc. Lon. 148: 585-593.

BURTON, M.R., ALLARD, P., MURE', F. \& OPPENHEIMER, C., 2003. FTIR remote sensing of fractional magma degassing at Mount Etna, Sicily. - In: Oppenheimer, 
C., Pyle, D.M. \& Barclay, J. (eds.): Volcanic degassing.- Geol. Soc. Lon. (Spec. pub.) 213: 281-293.

CALVARI, S. \& PINKERTON, H., 2004: Birth, growth and morphologic evolution of the 'Laghetto' cinder cone during the 2001 Etna eruption.- J. Volcanol. Geotherm. Res. 132: 225-239.

CALVARI, S., LODATO, L. \& SPAMPINATO, L., 2004: Monitoring active volcanoes using a handheld thermal camera.- Thermosense XXVI-SPIE, The International Society for Optical Engineering, 5405: 199-209.

CASADEVALL, T.J., ROSE, W.J., FULLER, W.H., HUNT, W.H., HART, M.A., MOYERS, J.L., WOODS, D.C., CHUAN, R.L. \& FRIEND, J.P., 1984: Sulphur dioxide and particles in quiescent volcanic plumes from Poás, Arenal, and Colima volcanoes, Costa Rica and Mexico.- J. Geophys. Res. 89: 9633-9641.

CASERTANO, L., BORGIA, A., CIGOLINI, C., MORALES, L., MONTERO, W., GÓMEZ, M.\&FERNÁNDEZ, J., 1985: Investigaciones geofísicas y características geoquímicas de las aguas hidrotermales: Volcán Poás, Costa Rica.- Geof. Int. 24: 315-332.

CASERTANO, L., BORGIA, A., CIGOLINI, C., MORALES, L.D., MONTERO, W., GÓMEZ, M. \& FERNÁNDEZ, J.F., 1987: An integrated dynamic model for the volcanic activity at Poás volcano, Costa Rica.Bull. Volcanol. 49: 588-598.

CHANCE, K., 1998: Analysis of BrO Measurements from the Global Ozone Monitoring Experiment.- Geophys. Res. Lett. 25: 3335-3338.

CHIODINI, G., VILARDO, G., AUGUSTI, V., GRANIERI, D., CALIRO, S., MINOPOLI, C. \& TERRANOVA, C., 2007: Thermal monitoring of hydrothermal activity by per- manent infrared automatic stations: Results obtained at Solfatara di Pozzuoli, Campi Flegrei (Italy).- J. Geophys. Res. 112: B12206. DOI: 10.1029/2007JB005140.

DEHN, J., DEAN, K.G., ENGLE, K. \& IZBEKOV, P., 2002: Thermal precursors in satellite images of the 1999 eruption of Shishaldin Volcano.- Bull. Volcanol. 64: 525-534.

DOUKAS, M.P., 2002: A new method for GPSbased wind speed determinations during airborne volcanic plume measurements.USGS Open-File Rep, 02-395: 1-13.

DOZIER, J., 1981: A method for satellite identification of surface temperature fields of subpixel resolution. - Remote Sensing Environ., 11: 221-229.

DUCE, R.A. \& HOFFMAN, E.J., 1976: Chemical fractionation at the air sea interface.- Ann. Rev. Earth \& Planet. Sci. 4: 187-228.

EDWARDS, D.J. \& DUDHIA, A., 1996: Reference Forward Model: High level algorithms definition.- ESA Doc. POMAOXF-GS-0004, Eur. Space Agency, Paris.

FAYT, C., \& VAN ROOZENDAEL, M., 2001: WinDOAS 2.1-Software User Manual, Belgisch Instituut voor Ruimte-Aëronomie, Institut d'Aéronomie Spatiale de Belgique, Brussels, Belgium.

FISH, D.J., \& JONES, R.L., 1995: Rotational Raman scattering and the ring effect in zenith-sky spectra.- Geophys Res. Lett. 22: 811-814.

FRANCIS, P.W., 1979: Infra-red techniques for volcano monitoring and prediction - a review.- J. Geol. Soc. Lond. 136: 355-359.

FOURNIER, N., RYMER, H., WILLIAMSJONES, G. \& BRENES, J., 2004: Highresolution gravity survey: Investigation of subsurface structures at Poás volcano, 
Costa Rica.- Geophys. Res. Lett. 31. DOI: 10.1029/2004GL020563.

HANSELL, A. \& OPPENHEIMER, C., 2004: Health hazards from volcanic gases: a systematic literature review.- Archives of Environmental Health, 59: 628-639.

HARRIS, A.J.L. \& MACIEJEWSKI, A.J.H., 2000: Thermal surveys of the Vulcano Fossa fumarole field 1994-1999: evidence for fumarole migration and sealing.- J. Volcanol. Geotherm. Res. 102: 119-147.

HARRIS, A.J.L., LODATO, L., DEHN, J. \& SPAMPINATO, L., 2009: Thermal characterization of the Vulcano fumarole field.Bull. Volcanol. 71: 441-458.

HERNÁNDEZ, P.A., PÉREZ, N.M., VAREKAMP, J.C., HENRIQUEZ, B., HERNÁNDEZ, A., BARRANCOS, J., PADRÓN, E., CALVO, D. \& MELIÁN, G., 2007: Crater lake temperature changes of the 2005 eruption of Santa Ana volcano, El Salvador, Central America.- Pure Appl. Geophys. 164: 2507-2522.

LOPES, R., (ed.), 2005: Volcanoes in Costa Rica.- In: The Volcano Adventure Guide. Cambridge University Press: 286-292.

MALICET, J.,DAUMONT,D., CHARBONNIER, J., PARISSE, C., CHAKIR, A. \& BRION, J., 1995: Ozone UV spectroscopy. II. Absorption cross-sections and temperature dependence.- J. Atmos. Chem. 21. DOI: 10.1007/BF00696757.

MARTIN, R.S., MATHER, T.A., PYLE, D.M., POWER, M., ALLEN, A.G., AIUPPA, A., HORWELL, C.J. \& WARD, E.P.W., 2008: Composition-resolved size distributions of volcanic aerosols in the Mt. Etna plumes.- J. Geophys. Res. 113. DOI: 10.1029/2007JD009648.
MARTIN, R.S., SAWYER, G.M., SPAMPINATO, L., SALERNO, G.G., RAMÍREZ, C., ILYINSKAYA, E., WITT, M.L.I., MATHER, T.A., WATSON, I.M., PHILIPS, J.C. \& OPPENHEIMER, C., 2010: A total volatile inventory from Masaya volcano, Nicaragua.- J. Geophys. Res. DOI: 10.1029/2010JB007484.

MARTÍNEZ, M., FERNÁNDEZ, E., VALDÉS, J., BARBOZA, V., VAN DER LAAT, R., DUARTE, E., MALAVASSI, E., SANDOVAL, L., BARQUERO, J. \& MARINO, T., 2000: Chemical evolution and volcanic activity of the active crater lake of Poás volcano, Costa Rica, 19931997.- J. Volcanol. Geotherm. Res. 97: 127-141.

MATHER, T.A., PYLE, D.M., TSANEV, V.I., MCGONIGLE, A.J.S., OPPENHEIMER, C. \& ALLEN, A.G., 2006: A reassessment of current volcanic emissions from the Central American arc with specific examples from Nicaragua.- J. Volcanol. Geotherm. Res. 149: 297-311.

MCGONIGLE, A.J.S., OPPENHEIMER, C., GALLE, B., MATHER, T.A. \& PYLE, D.M., 2002: Walking traverse and scanning DOAS measurements of volcanic gas emission rates.- Geophys. Res. Lett. 29. DOI: $10.1029 / 2002$ GL015827.

MELIÁN, G.V., GALINDO, I., PÉREZ, N.M., HERNÁNDEZ, P.A., FERNÁNDEZ, M., RAMÍREZ, C., MORA, R. \& ALVARADO, G.E., 2007: Diffuse emission of hydrogen from Poás Volcano, Costa Rica, America Central.- Pure Appl. Geophys. 164: 2465-2487.

MORA, R., RAMÍREZ, C. \& FERNÁNDEZ, M., 2004: La actividad de los volcanes de la Cordillera Central, Costa Rica, entre 19982002.- Rev. Geol. Amér. Central, 30: 189-197. 
MORA-AMADOR, R., ALVARADO, G.E. \& RAMÍREZ, C.J., 2007, Recent Fumarolic Activity and Sulphur Eruptions at Poás Volcano (Costa Rica).- El Chichón Volcano: Twenty-five years later. A Commemorative Conference - San Cristóbal de las Casas, Chiapas, México. Universidad Nacional Autónoma de México, Instituto de Geología, Publicación Especial 6: 74.

MORA-AMADOR, R. \& RAMÍREZ, C.J., 2008: Sulphur flows at Poás volcano, Costa Rica. - IAVCEI 2008 - General Assembly - Reykjavík - Iceland, 52.

NESHYBA, S., FERNÁNDEZ, W. \& DIAZANDRADE, J., 1988: Temperature profiles from Poás crater lake.- EOS, Transactions American Geophysical Union, 69: 588 .

NOXON, J.F., 1975: Nitrogen dioxide in stratosphere and troposphere measured by ground-based absorption spectroscopy.Science, 189: 547-549.

OHBA, T., HIRABAYASHI, J., \& NOGAMI, K., 1994: Water, heat and chloride budgets of the crater lake, Yugama at Kusatsu-Shirane volcano, Japan.- Geoch. J. 28: 217-231.

OHBA, T., HIRABAYASHI, J., \& NOGAMI, K., 2000: D/H and 18O/16O ratios of water in the crater lake at Kusatsu-Shirane Volcano, Japan.- J. Volcanol. Geotherm. Res. 97: 329-346.

OPPENHEIMER, C. \& STEVENSON, D., 1989: Liquid sulphur lakes at Poás volcano.Nature, 342: 790-793.

OPPENHEIMER, C., 1992: Sulphur eruptions at Volcán Poás, Costa Rica.- J. Volcanol. Geotherm. Res. 49: 1-21.
OPPENHEIMER, C., 1993: Infrared surveillance of crater lakes using satellite data.- J. Volcanol. Geotherm. Res. 55: 117-128.

OPPENHEIMER, C., 1997: Ramifications of the skin effect for crater lake heat budget analysis.- J. Volcanol. Geotherm. Res. 75: 159-165.

PERNER, D., \& PLATT, U., 1979: Detection of Nitrous Acid in the Atmosphere by Differential Optical Absorption.- Geophys. Res. Lett. 6: 917-920.

PFEFFER, M.A., RIETMEIJER, F.J.M., BREARLEY, A.J. \& FISCHER, T.P., 2006: Electron microbeam analyses of aerosol particles from the plume of Poás Volcano, Costa Rica and comparison with equilibrium plume chemistry modelling.- J. Volcanol. Geotherm. Res. 152: 174-188.

PLATT, U., \& STUTZ, J., 2008: Differential Optical Absorption Spectroscopy Principles and Applications.- 597 págs. Series: Physics of Earth and Space Environments. Springer.

RAMÍREZ, C., MORA-AMADOR, R. \& GONZÁlEZ, G., 2010, Physical changes before and during the new period of phreatic eruptions, Poás Volcano 20062010, Costa Rica. - IAVCEI Commision of Volcanic Lakes (CVL) - 7th Workshop on Volcanic Lakes, San José, Costa Rica, 30-31.

RED SISMOLÓGICA NACIONAL (RSN: UCRICE), 2009, El terremoto de Cinchona del jueves 8 de enero del 2009.- Rev. Geol. de Amér. Central, 40: 91-95.

ROBINSON, I.S., WELLS, N.C. \& CHARNOCK, H., 1984: The sea surface thermal boundary layer and its relevance to the measurement 
of sea surface temperature by airborne and spaceborne radiometers.- Int. J. Remot. Sens. 5: 19-45.

RODGERS, C.D., 1976: Retrieval of atmospheric temperature and composition from remote measurements of thermal radiation.- Rev. Geophys. 14: 609-624.

ROTHMAN, L.S., JACQUEMART D., BARBE, A., BENNER, D.C., BIRK, M., BROWN, L.R., CARLEER, M.R., CHACKERIAN JR, C., CHANCE, K., COUDERT, L.H., DANA, V., DEVI, V.M., FLAUD, J.M., GAMACHE, R.R., GOLDMAN, A., HARTMANN, J.-M., JUCKS, K.W., MAKI, A.G., MANDIN, J.-Y., MASSIE, S.T., ORPHAL, J., PERRIN, A., RINSLAND, C.P., SMITH, M.A.H., TENNYSON, J., TOLCHENOV, R.N., TOTH, R.A., VANDER AUWERA, J., VARANASI, P. \& WAGNER, G., 2005: The HITRAN 2004 molecular spectroscopic database.- J. Quant. Spectrosc. Radiat. Transfer, 96: 139-204.

ROWE, G., OHSAWA, S., TAKANO, B., BRANTLEY, S., FERNÁNDEZ, J. \& BARQUERO, J., 1992a: Fluid-volcano interacting in an active stratovolcano: The Crater Lake system of Poás Volcano, Costa Rica.- J. Volcanol. Geotherm. Res. 49: 23-51.

ROWE, G.L., OHSAWA, S., TAKANO, B., BRANTLEY, S.L., FERNÁNDEZ, J.F. \& BARQUERO, J., 1992b: Using crater lake chemistry to predict volcanic activity at Poás Volcano, Costa Rica.- Bull. Volcanol. 54: 494-503.

RYMER, H. \& BROWN, G., 1989: Gravity changes as a precursor to volcanic eruption at Poás volcano, Costa Rica.- Nature, 342: 902-905.

RYMER, H., CASSIDY, J., LOCKE, C.A., BARBOZA, M.V., BARQUERO, J., BRENES, J. \& VAN DER LAAT, R., 2000: Geophysical studies of the recent 15-year eruptive cycle at Poás Volcano, Costa Rica.- J. Volcanol. Geotherm. Res. 97: 425-444.

RYMER, H., LOCKE, C.A., BRENES, J. \& WILLIAMS-JONES, G., 2005: Magma pluming processes for persistent activity at Poás Volcano, Costa Rica.- Geophys. Res. Lett. 32, L08307.

SALIBURY, J.W. \& D'ARIA, D.M., 1992: Emissivity of terrestrial materials in the 8-14 $\mu \mathrm{m}$ atmospheric window.- Rem. Sens. Envirn. 42: 83-106.

SANFORD, W.E., KONIKOW, L.F., ROWE, G.L. \& BRANTLEY, S.L., 1995: Groundwater transport of crater-lake brine at Poás Volcano, Costa Rica.- J. Volcanol. Geotherm. Res. 64: 269-293.

SAWYER, G.M. \& BURTON, M.R., 2006: Effects of a volcanic plume on thermal imaging data.- Geophys. Res. Lett. 33, DOI: 10.1029/2005GL025320. 
SAWYER, G.M., CARN, S.A., TSANEV, V.I., OPPENHEIMER, C. \& BURTON, M.R., 2008: Investigation into magma degassing at Nyiragongo volcano, Democratic Republic of the Congo.- Geochem. Geophys. Geosyst. 9. DOI: 10.1029/2007/ GC001829.

SMITHSONIAN, 1987: http://www.volcano. si.edu/world/volcano.cfm?vnum $=1405$ 04=\&volpage=var\#sean_1208 08/ 1987 (SEAN 12:08).

SOLOMON, S., SCHMELTEKOPF, A.L. \& SANDERS R.W., 1987: On the interpretation of zenith sky absorption measurements.- J. Geophys. Res, 92: 8311-8319.

STOIBER, R.E., MALINCONICO, L.L. \& WILLIAMS, S.N., 1983: Use of the correlation spectrometer at volcanoes.- In: TAZIEFF, H. \& SABROUX, J.C. (eds.): Forecasting volcanic events.- Elsevier, Amsterdam: 425-444.

STOIBER, R.E., WILLIAMS, S.N., \& HUEBERT, B.J., 1986: Sulfur and halogen gases at Masaya caldera complex, Nicaragua: Total flux variation with time.- J. Geophys. Res. 91: 12215-12231.

TRUNK, L. \& BERNARD, A., 2008: Investigating crater lake warming using ASTER thermal imagery: Case studies at Ruapehu, Poás, Kawah Ijen, and Copahue' Volcanoes.- J. Volcanol. Geotherm. Res. 178: 259-270.
VANDAELE, A.C., SIMON, P.C., GUILMOT, J.M., CARLEER, M. \& COLIN, R., 1994: $\mathrm{SO}_{2}$ Absorption Cross Section measurement in the UV using a Fourier Transform Spectrometer.- J. Geophys. Res. 99: 25599-25605.

VAREKAMP, J.C., OUIMETTE, A.P., HERMAN, S.W., BERMUDEZ, A. \& DELPINO, D., 2001: Hydrothermal element fluxes from Copahué, Argentina: a "beehive" volcano in turmoil.- Geology, 29: 1059-1062.

VASELLI, O., TASSI, F., MINISSALE, G., MONTEGROSSI, G., DUARTE, E., FERNÁNDEZ, E. \& BERGAMASCHI, F., 2003: Fumarole migration and fluid geochemistry at Poás volcano (Costa Rica) from 1998 to 2001.- In: OPPENHEIMER, C., PYLE, D.M. \& BARCLAY, J. (eds.): Volcanic degassing.- Geol. Soc. Lon. (Spec. pub.) 213: 247-262.

WILLIAMS-JONES, G., STIX, J. \& HICKSON, C., 2008: The COSPEC Cookbook: Making $\mathrm{SO}_{2}$ Measurements at Active Volcanoes.IAVCEI, Methods in Volcanology, 1.

ZIMMER, M.M., FISCHER, T.P., HILTON, D.R., ALVARADO, G.E., SHARP, Z.D. \& WALKER, J.A., 2004: Nitrogen systematics and gas fluxes on subduction zones: Insights from Costa Rica arc volatiles.Geochem. Geophys. Geosyst. 5. DOI: 10.1029/2003GC000651. 